The Heritage Arts Imperative

Author(s): Barre Toelken

Source: The Journal of American Folklore, Vol. 116, No. 460 (Spring, 2003), pp. 196-205

Published by: University of Illinois Press on behalf of American Folklore Society

Stable URL: http://www.jstor.org/stable/4137898

Accessed: 23-03-2016 15:09 UTC

Your use of the JSTOR archive indicates your acceptance of the Terms \& Conditions of Use, available at http://www.jstor.org/page/ info/about/policies/terms.jsp

JSTOR is a not-for-profit service that helps scholars, researchers, and students discover, use, and build upon a wide range of content in a trusted digital archive. We use information technology and tools to increase productivity and facilitate new forms of scholarship. For more information about JSTOR, please contact support@jstor.org. 


\section{The Heritage Arts Imperative}

TO BEgIN WITH, I NEED TO MAKe A DISClAIMER: I will be referring to the culturally based arts of several different kinds of communities, including ethnic and national groups to which I do not belong. I do not pretend to be a spokesperson for any of them. Indeed, I urge you to find a way to listen to the voices of those communities and to experience their arts directly, not only through my well-intentioned but peripheral comments. Unfortunately, we often encounter the arts in academic or formally organized settings where the articulate voices of everyday living cultures are not readily heard. One result is that we tend easily toward seeing art as Art; another is that traditional folk art seldom shows up in discussions of what art is and what it does for us. My purpose here is to suggest that it is imperative that we pay closer attention to the arts that arise from what has been loosely called "cultural heritage"- the ongoing accumulation of expressive forms that represent the shared tastes and experiences of living cultures more than they demonstrate the unique strides of particular brilliant artists. This is a richer, far more complex topic than anyone can properly treat in a brief address, so obviously my comments will be suggestive rather than definitive.

Thus I will not begin with an academic commentary on the central role of folklore in Shakespeare's and Chaucer's works, or on Mozart's use of folk melodies and chord progressions, or on Bartók's or Copland's borrowing of folksong themes and motifs, or on the employment by modern visual artists of Native American designs and color contrasts. Nor will I expound on the interesting backstage folk customs and beliefs of theatre and opera people. I will not bore you with yet another complaint about those who persist in calling the work of untrained geniuses "folk art." Rather, I want to enlarge upon a topic with which you are already familiar to one extent or another, but one that has never received enough serious conversation: the importance, the validity, the necessity to include folk arts, heritage arts, and fine arts in connection with each other, in the same conversation. I will concentrate on the folk arts here, but not in contradistinction to other arts. I see all arts as existing along a kind of spectrum, ranging from expressions in which community values and aesthetics impinge upon the artist to expressions in which the artist impinges upon the culture. While all art exists somewhere on this spectrum, most of what we call the folk or culturally situated arts are found close to the first category.

On the wall of my office, I have a set of three panoramic photographs showing the valley in central Massachusetts where I was born. The first one, in black and white,

BARRE TOELKEN is Professor of English and History, Utah State University, Logan

This essay is a revised version of an invited lecture to the National Council of the National Endowment for the Arts in Washington, D.C., March 9, 2001. 
shows the town of Enfield, a typical New England farming town with a couple of church spires, photographed from nearby Mount Quabbin in 1927. The next, taken from the same spot, shows the valley in 1939, after it had been entirely cleared of buildings. The third shows the valley today, full of water. Now called Quabbin Reservoir, it supplies drinking water for the Boston area about ninety miles away. I imagine that most Bostonians don't even know their water comes from a valley where five pretty towns and several quaint villages once thrived, much less that it has been a custom over the intervening years for Quabbinites to return the ashes of their parents (or other memorabilia) to the water there ("How else can we get back at them?" my mother demanded to know). My earliest memories are of watching the houses going by on the road below our place, some pulled by large teams of horses. Some people have kept track of where their houses went and occasionally visit their former homes on the newer foundations all over New England. I keep the photo to remind me of my roots since the town of Enfield physically isn't "there" anymore. Of course, the reality of Enfield is not in the photo; it is, rather, in the heads of those of us who are left. In my case it gets expressed in the customs I share with my children and grandchildren today in the riddles, sayings, dialect variations, and especially old songs and ballads that were passed down to us through my mother's family heritage, a rich store of vernacular, everyday arts that were happily at home in the Quabbin Valley for many generations before the place ironically lived up to its Native American name: Land of Many Waters.

On the wall at home is yet another panoramic photo: My wife, her two brothers, their parents, and a handful of relatives are standing in 300 acres of growing flowers. The scene is San Fernando Valley in 1939; the foothills are visible in the background, and Van Nuys Boulevard, still unpaved, is in the lower-right corner. Two years later, during the event now known antiseptically as "The Relocation," all the people living there were given twenty-four hours to move, taking only what they could carry. The picture is one of the things they chose to bring along, to remind them of where they came from. Like my valley, their farm isn't physically there anymore; it is as deep in parking lots, banks, and estate subdivisions as Quabbin is deep in water. But their family reality is still intact, expressed in old customs and traditions of expressive gardening. Their ethnic identity survives, expressed in dance, lullabies, martial arts, embroidery, language, and especially in foods. Their DNA is from Japan; their citizenship is of the United States; their heritage is that of Japanese Americans whose everyday customs in food and language preserve and perpetuate traditions that have actually become rare in Japan. Our family photos remind us of where we came from, but our family and ethnic heritages remind us of who we are and provide for us ways of expressing, experiencing, and living who we are culturally. And, of course, all these expressive forms are aspects of art-not of politics, education, race, or economics. Call them folk arts if you will, or vernacular arts, or the artistic heritage of everyday life; but these are the living and dynamic means by which cultures-all cultures-continue to exist, and they do not depend on studio space, legal obligation, institutional instruction, educational certification, or income.

Scholars once thought that everyday cultural traditions were dying out, or that they could be found mostly among the poor, the rural, and the uneducated. We now know 
that there are more folk expressions than ever because there are more people interacting expressively (now even electronically) than ever before, and in this increased interchange some customs become modified, new ones are developed, others get dropped, and still others are intensified. It is not just a cliché that the "melting pot" metaphor has been replaced by "salad," or "stew," or "mosaic"; rather, such a hybrid approach has become a cultural reality, and it was central to the findings on which the American Folklife Center was grounded in 1976 (see Public Law 94-201 for the declaration that "building a strong nation does not require the sacrifice of cultural differences"). What we sometimes miss in the growing cultural diversity of our country is that many people are becoming more aware of their own familial and cultural heritage in contrast or in relation to those of other families, other ethnicities, other regions. This heightened awareness may range from relatively trivial issues, such as differences in the tradition of opening presents on Christmas Eve or on Christmas morning, or whether lutefisk, sashimi, walrus flipper, or hotdogs are indeed edible, to more complicated matters dealing with language, behavior, courtship, marriage, childrearing, aging, death, burial, and other rites of passage.

Beyond that, all cultures have strong traditions of artistic performance, each one imbued with a sense of propriety, meaning, and culturally shaped aesthetics. On the emotional level, we know from current events that in some countries culture is so deeply important that people are willing to fight and die for it. In America, cultureespecially culturally structured and nurtured art-does matter, not only as an index of potential political power (or trouble) abroad or financial success on the world market as argued by Lawrence E. Harrison and Samuel P. Huntington in their recent book, Culture Matters (2000), but also as a living demonstration that our constituent cultures at home are still alive, functioning, and expressing themselves in artistic forms that they choose to perpetuate. What is important about this, and how does folklore relate to it?

When people migrate to a new land (and of course, except for our predecessors, the Native Americans, all American ancestors have done so), they leave physical belongings behind, but they carry along with them their culture, their language, their shared sense of values-mostly archived in the many expressive forms of everyday life, such as stories, music, dance, food, and ritual. Why wouldn't they? How could they do otherwise? Everything, from their lullabies and popular songs to their classical forms, remains important-oftentimes even more important-when far from home. Eventually, some of these expressions will die out, others will survive intact, and others will be modified by new experiences. The traditions and expressions that remain will often become intensified. Some may even become icons of cultural identity. For example, the cultivation of bonsai, calligraphy, flower arrangement, and classical dance (once the province of the upper classes in Japan) have become expressive ways of participating in an ongoing, yet emerging, cultural heritage (versus nationality) among Japanese Americans. Simultaneously, playing the taiko drum-which one hears mainly at festivals and on ritual occasions in Japan-has become a galvanizing force at social events among young third- and fourth-generation Japanese Americans. Lullabies long forgotten in Japan are still sung by Nisei (first-generation) grandmothers in the United States. Clearly, this picture does not represent the way 
culture is perceived and lived in Japan today, but rather these traditions mark the way Japanese culture is preserved and reexperienced by transplanted Japanese people in the United States. Multiply this Japanese example by the hundreds of other cultures that now reside in the United States. Cultural heritage in America is made up of selected and intensified expressions that are symbolic of every people's shared, enduring artistic experience.

Folklorists have called this phenomenon of intensified preservation of culture following migration "marginal distribution," or "peripheral distribution," meaning that we often find enduring and culturally important artistic forms out on the periphery, margin, or far edge of a people's migration. In the old homeland, culture and language continue to be modified and naturally change, but out on the margins, among people trying to maintain a cultural identity in new places, arts often become more noticeably conservative and yet, of course, also dynamic and emergent due to their performance in a fresh setting. Since the United States has been the destination of so many cultures over the past several centuries, America has been the lucky beneficiary of lively expressive forms earnestly cultivated, nurtured, and refashioned by people for whom artistic heritage is a powerful agent for stability and belonging. The result is that the United States, like no other nation, has become the artistic "margin" for a multiplicity of culturally shaped arts. Where else can you find English/Scottish ballads, which have died out in most of the British Isles, still being sung, or medieval dramas no longer extant in Spain but being enacted by hybrid communities in $\mathrm{New}$ Mexico (to name only a few).

The so-called hyphenated Americans have often come under suspicion of being somehow unfaithful to their new abode by not giving up their old ties, but that kind of thinking misses a most significant point. When groups use a term like "German American," as we do on my father's side of the family, we are saying two important things: I come from a German cultural background that has shaped much of my personal and family identity, and I am a citizen of the United States, which shapes my political and social identity. And of course I can say the same thing about the English heritage on my mother's side. In this formula, the cultural identifiers do not exclude or downgrade the political reality; in fact, they enrich it. In the 1980 census, which allowed Americans the option of naming a "nationality" other than American, more than 90 percent of the people in Wisconsin, Minnesota, and North Dakota listed a cultural identifier - a percentage matched only by respondents living in Hawaii. Some of these people must have been recent immigrants, but certainly the figure represents a substantial claim for the importance of imported ethnicity among most Americans: their consciousness of another kind, time, and place, now residing in the United States.

Steve Siporin's 1992 book, American Folk Masters, an account of the first ten years of the NEA's National Heritage Fellows program, provides an eloquent testimony of the extraordinary ways in which our own neighbors and fellow citizens continue to experience and share their ethnic and national identity through stunning articulations of cultural meaning and aesthetic taste. Many of the art forms featured through the NEA programs originated in foreign lands but are now intensely at home in the United States as vernacular icons. In addition to the folk arts, think of the everincreasing examples of immigrant classical and popular arts now resident and thriving 
in American contexts: Chinese opera, Indian sitar music, gamelan orchestras; Korean classical dance, Greek/Tongan/Hawaiian/Samoan/Vietnamese dance; Mexican murals, ballets folkloricos, mariachi bands; African tribal drums, dancing, woodcarving, textile arts; Tibetan weaving, Hmong embroidery; "Dutch," Ukrainian, and Polish bands; Swiss yodelers; and Irish button-accordion players. Add to this list the Native American arts that have remained the backbone of threatened tribes and have nurtured the resurgence of tribal pride since the devastating wars and relocation of the last century. Just the dance tradition called powwow-among many possible examplesdemonstrates the dynamism of art forms among contemporary Indian people: combining dance, design, color, craftsmanship, rhythm, music, and tribal custom. Over the past eighty to one hundred years the powwow has become an exciting integrative force in the intertribal society Indians live in today. People who 150 years ago spoke entirely different languages - and were perhaps even enemies-now use the metaphor of dancing together to express shared concerns ranging from the religious to the aesthetic to the political to the recreational-just as dance is used in all cultures.

Let us not forget the massively reshaped and sometimes altogether new art forms that resulted from cultural intersections in the New World: among the most obvious examples, the so-called mestizo cultures combined Spanish and Indian tastes to develop arts, dances, and music that did not previously exist either in the Americas or in Spain. The mixture of French and Native cultures in the north brought about newly energized expressions, among them a strong Native fiddling tradition more widespread now in Canada and Alaska than it is today in France. In the Russian Orthodox church in Sitka, Alaska (headquarters of the Russian Orthodox Church in North America), you can hear a choir made up of Tlingits and Aleuts singing the liturgia in four-part Russian harmony. And in dramatic fashion, in a process still not fully understood or appreciated, the forceably imported African slaves, denied family, language, and tribal affiliations that might have helped them maintain an African identity in their new circumstances, combined a wide variety of musical and dance expressions with the language and musical instruments of their captors and produced-among other things-a vital musical tradition that has had an immense effect on almost all American music ever after.

It is true, of course, that not everything in this picture is rosy. In the processes of immigration and socialization, and especially where racial or class differences impinge, some cultures, and the arts they produce, have been brought close to the edge of extinction; some, indeed, have been eradicated. The artistic impact of slavery, in addition to its other outrages, is impossible to calculate. And of the 500-plus languages once spoken from Mexico northward, only about 150 remain. Of course even that much retention is remarkable in the face of intense social and even legal pressures to adopt the dominant language, but the human and artistic loss cannot be underestimated. For example, when Franz Boas collected stories from the northwest coast Chinook at the turn of the last century, one of his resources, Charles Cultee, was one of the last three people who could speak the Kathlamet Chinook language. Two or three years later, they were all gone. Fortunately for us all, the text of "The Sun's Myth" was preserved, and it has emerged as one of the world's great classics-not as long or as complicated as the Iliad or the Odyssey - but equally moving in its dramatization 
of the devastating effects of human selfishness. And we came that close to not knowing about it at all (see "The Sun's Myth" [1996]). But what else have we lost in the area of oral literature? Art? Dance? Music? Healing traditions? The possibilities here rival those of the disappearing forests of the Amazon basin, where potential medicines and healing practices are being destroyed every day. In the case of the heritage arts, the loss represents a silent, cultural impoverishment. Fortunately, and against overwhelming odds, many Native tribes have maintained or recovered their oral traditions. We will inevitably discover that these culturally situated stories-like all artsnot only nurture and sustain those who tell them and hear them, but enrich the rest of us as well.

The work of Eva Castellanoz, a curandera and folk artist living in Nyssa, Oregon, represents a set of traditions often viewed with scorn or condescension by the larger society that surrounds her. She is a folk healer, an herbalist, who believes that plants and minerals do not exist coincidentally but are placed in her environment for her to use against both physical and mental illnesses. From paper, melted wax, and odd bits of found objects, she also produces the delicate crowns, bouquets, sprays, and ritual ropes used in Hispanic customs associated with coming of age, marriage, and death. As she shapes a wax-dipped flower from some leftover colored paper, she says quietly, "See, colored paper makes beautiful flowers, too; it doesn't always have to be white. We shape our children like we shape these flowers. We don't throw them away because they are darker in color." With her quiet manner and careful art, Eva has become a central force in a project called Hispanic Youth on the Move, counseling and nurturing Hispanic youths who feel alienated from the surrounding culture. She uses the vernacular arts of her culture, not sociology: the last time I saw her, she had a small group of very tough-looking kids making delicate coronas for upcoming quinceaneras in their families. She makes a real difference with her art. If it were not for Siporin's book, however, she would be largely unknown, a marginal artist working in forms and media not widely recognized by our art community. On the other hand, the carving of wooden santos, once believed to be a vanishing tradition among Hispanic artists in New Mexico and California, is now enjoying a resurgence-not only because the culturally rendered saints have become popular in the art world, but because young Latinos are buying them in greater numbers as guides to making the right choices in marriage and occupation.

Some years ago, African American quilts were considered by quilting specialists to be generally unsatisfactory attempts at the genre. African Americans, it was quietly rumored, had just not caught on to the necessities of symmetry, color balance, and traditional design. Their quilts often had blocks of color at one end which were not matched at the other end, or sometimes a square or a segment of the pattern was put in backwards, or on a slant. In those days, Black quilts did not show up very often in exhibitions. But a few years ago, quilt experts began to listen to African American folklorists and learned that the designs and colors used by African American quilters are reminiscent of West African fabric design. Suddenly the lights went on: in African textile custom, colors are often concentrated at one end of a piece, washing into something else at the other end; design features are altered with intent, sometimes whimsically, sometimes marking a vital cultural message or image, thus creating dif- 
ferent quilt aesthetics; colors are often produced from vegetable or mineral dyes; parts of the design may be in circles, rather than the Anglo preference for linear design, and so on. In addition, when an exhibition of African American quilts finally appeared about twenty years ago at the National Gallery, a number of them had their corners turned up to show the reverse side, for researchers discovered that Black quilters had used flour sacks as backing, often preferring the ones featuring stereotypical prints of "pickaninnies" as advertising logos-a wonderful case of social commentary and artistic cooptation of a derogatory symbol.

The breakthrough in African American quilts came about because more people became aware of the imperative to look seriously at the dynamism of an art form for what it expressed in its own culture. Until that point, the art was not found in museums and art books very often because the so-called quilt experts had not yet learned to recognize the shared cultural depth and richness of the medium in its own terms. Indeed, while many of the lively art forms I have mentioned do find some financial support from folk arts programs around the country, on the whole, "heritage arts" have not been viewed as being in the same aesthetic ballpark as formal art, or more recognized "folk art" forms. When I served on the NEA Folk Arts Panel, we often had applications referred to us by other endowment programs that did not quite know what to do with Chinese opera or Hawaiian hula. While the situation today at the NEA is much better, I still have the feeling that many Americans are most at ease with art forms informed by formal Euro-American assumptions.

Yanagita Kunio, a prominent Japanese folklorist who died in 1962, pointed out that only a small portion of any culture becomes enshrined and protected in museums and presented on stage. Most often the living artists of everyday life, people who do not come to the attention of the larger society, and who thus do not attain fame or notoriety, are actually the primary active carriers of culture and are therefore of central importance, whether they come to our attention or not. If every museum were leveled by earthquake or war, Yanagita pointed out, it would be a terrible loss, but it would not destroy culture, which would continue to thrive as long as people continued to express themselves in culturally constructed forms (Yanagita Kunio, quoted in Koschmann 1985:153). If all the log cabins or quilts or moccasins or violins or sitars in America were destroyed, it would not be the end of those arts, for we still have people who can "do" them again; the arts are alive in our various cultures.

The artistic urge among humans is universal and ancient: It makes up the core of all cultures. Indeed, what we know of older cultures comes primarily through the arts. From the hunters' caves at Lascaux, to the buildings and frescoes at Pompeii, to baskets and pots and woven sandals in the Anasazi ruins, the oldest and most precious signs of our own being exist mainly in artistic form. Ranging from ancient petroglyphs to more modern expressions such as spray-can graffiti, rawhide braiding, or alpine yodeling, the arts-and here I mean especially the arts that arise almost spontaneously from meaningful cultural contexts-remain the most abiding signatures of human meaning. Like my old photos, objects like bones, fossils, and practical utensils tell us where we have been and what we have been doing. But the unnecessarily beautiful arrowheads, baskets, ceramics, and carvings; the boat designs and regional 
architecture; quilt symmetries and their cultural variations; the quill work, bead work, hide work; the songs, dances, and instruments; the culturally shaped fabrics and foods, plus the expressive customs that provide the performative context for all these arts, show us who we are and what our aesthetic values have been.

By nurturing and encouraging these basic and dynamic cultural arts in the everyday lives of everyday people with the same intensity with which we have always promoted the more formal arts, we will be supporting arts in the most important way: acknowledging their deep significance on all levels of human experience; making a claim for their role in the richness of the whole society; and showing their relationships to the issues and values which concern us all. Urging that cultural heritage is central in the arts is not a matter of political correctness or of warm, happy inclusivity. Rather, it is an exercise in reality: the cultural diversity is already there, the heritage arts are already there. If we are really dedicated to the proposition that arts are of utmost importance to us all, then to ignore or downplay the artistic riches of our multiple cultures - many of which have been centuries in the making-would surely be short-sighted, if not dim-witted.

I know that some have whined that a greater cultural inclusiveness by the National Endowments would somehow dilute, "dumb down," or trivialize the arts. I will not mention names at this point, but suffice it to say, such critics are walking on thin ice. Our people dumb? Our cultures trivial? I don't think so, and I don't think it is in the interests of a democracy to let such ideas get any farther than the wastebasket. To be sure, a more inclusive view does weaken the notion that "real art" is exclusive stuff, produced in studios only by persons of rare talent and merit for consumption by connoisseurs of elevated-shall we say "elite"? - tastes. Sure enough, a serious consideration of heritage arts does bring that proposition into question. And it should. The fact is that while most of us are not, by ourselves, in a position to compose a ballet or produce a pair of beaded moccasins with the pattern facing in the right direction, direct a symphony, or piece a Tongan quilt, we are surrounded by both talented individuals and talented cultures who do have the capacity to create those traditional arts, and it is neither dumb nor trivial to make the claim for it.

A prominent journalist who persists in knowing nothing about folklore recently attacked the field of folklore as well as the Endowments' interest in things traditional, apparently in the mistaken notion that there would soon be a rash of federal grants for making corncob pipes and singing in the car on the way to Grandma's. Nebraska folklorist Roger Welsch (who occasionally appears on CBS's "Postcard from Nebraska" during the Sunday morning show) responded on this occasion to his friends in the following e-mail message (from which I have deleted a few words): "Friends, I am about to collapse in jealousy. In today's syndicated George Will column . . . he does us all honor by attacking folklore studies, and by name and with his usual selfrighteousness also assaulting Bill Ferris and Bill Ivey. If any of you has contact with either of these guys, please pass on to him or them my enormous admiration and envy" (quoted with permission of Roger Welsch).

Ignorance of the field of folklore (or, for that matter, anthropology, social history, cultural studies, or art history) by a major columnist may be forgivable —or at least 
understandable - given the fact that most people do not know what specialists in these fields do today. But the venom is worth our attention, for it dramatizes the fear or contempt many people have of other cultures, fear of unschooled and uncontrolled vernacular activity, fear-even - of everyday democracy, fear that something they consider "trivial" and common, and thus beneath their dignity, might actually be important after all.

If there is an argument for triviality, it would be only in the original Latin meaning of the expression from which we get the word: tri via, that is, three roads, an intersection where three roads come together. Think of roads in Roman times: three roads would not intersect for no reason at all. The trivia is the place where everybody's path crosses; it is an important, not a trifling place. It is a place of commonality and diversity - heavy traffic, with all sorts of people and cultures running into each other. It is a place where people meet and talk, and set up markets. That is the whole point of an intersection. And, yes, the trivia isn't exclusive; it is a center of human activity. And isn't this what we believe about the arts?

Scientists tell us that diversity is the key to survival and evolution among plants and animals. The more we restrict diversity in our ecological systems, we are told-such as by suppressing bothersome species - the more we impede the survivability of other living things. That is only an analogy, of course, but I would suggest that the same can be said of diversity in the world of art. Of course, people will continue to produce art anyway, but in our organized attempts to encourage, nurture, and fund the arts, the rich and energetic diversity of heritage arts not only offers us masterworks we might not otherwise see, but also provides a demonstration of the basic artistic urge among all peoples, no matter how different they may seem. In this, we see that diversity is only a part of the picture, for the commonalities of artistic expression unite us as human beings, just as the variations in performance and genre commemorate our distinctive backgrounds. I was startled one time to hear an elderly whittler, Verne Schaeffer of Malad, Idaho, say that when he carves a chain or a ball-in-the-box, he just cuts away anything that doesn't look like a chain or a ball. Just a few weeks earlier I had been in tiny Mountain Village on the Yukon River and had asked Yupik carver Waskey Walters how he came up with his designs (mostly ghosts, monsters, and animals) and he had replied-as though the answer was obvious-that he looked for whatever was there in the wood and then cut away everything that didn't look like that. These two artists, thousands of miles apart in geography and culture, were giving local, vernacular voice to an idea attributed to virtually every well-known sculptor, including Michelangelo and Rodin. Our job, it seems to me, is to capitalize on insights like this so that we can bring people to a wider awareness that art is not the exclusive playground of the wealthy and the privileged, but the inheritance-the heritage if you will —of us all. From the most elegant ballet to the quiet beauty of a grass basket, art relates more of us and intersects more of us than does any other association-political, social, religious, or philosophical. The more fully we can demonstrate this common interest, the more legitimately we can claim that art is worth every penny we spend on it. It is not impossible to expect that in so doing we may well develop a larger and more fully conscious audience for all the arts. 


\section{References Cited}

Harrison, Lawrence E., and Samuel P. Huntington, eds. 2000. Culture Matters: How Values Shape Human Progress. New York: Basic Books.

Koschmann, J. Victor. 1985. Folklore Studies and the Conservative Anti-Establishment in Modern Japan. In International Perspectives on Yanagita Kunio and Japanese Folklore Studies, Cornell University East Asian Papers 37. Ithaca, N.Y.: Cornell University Press.

Siporin, Steve. 1992. American Folk Masters: The National Heritage Fellows. New York: H. N. Abrams; Santa Fe: in association with the Museum of International Folk Art.

“The Sun's Myth." 1996. In Coming to Light: Contemporary Translations of the Native Literatures of North America, ed. Brian Swann, ed. and trans. Dell Hymes, pp. 273-85. New York: Vintage. 